\title{
Some Approaches to Developing a Test Method for Determining the Actual Fire Resistance Limit of Façade Translucent Structures
}

\author{
Tatiana Eremina ${ }^{1}$, Dmitry Korol'chenko ${ }^{1}$, Mikhail Vasiliev², Leonid Tanklevskiy ${ }^{2,3 *}$, and \\ Mikhail Eremin ${ }^{4}$ \\ ${ }^{1}$ National Research Moscow State University of Civil Engineering (NRU MGSU), 129337, 26 \\ Yaroslavskoye shosse, Moscow, Russia \\ ${ }^{2}$ Peter the Great St. Petersburg Polytechnic University, 195521 Polytechnicheskaya, 29, Saint- \\ Petersburg, Russia \\ ${ }^{3}$ FSBEE HE «Saint-Petersburg University of State Fire Service of EMERCOM of Russia», 196105, \\ Moskovsky prospect, 149, Saint-Petersburg, Russia \\ ${ }^{4} 36$ th Fire and Rescue Unit of the Federal Fire Prevention and Rescue Service of the State Fire \\ Service of Vasileostrovskii district of the Main Directorate of the Ministry of Emergency in St. \\ Petersburg
}

\begin{abstract}
Based on the analysis of modern construction of high-rise buildings with façade translucent structures (FTS), it was established that the actual fire resistance limit of FTS for high-rise buildings should be assessed. The criterion for loss of fire resistance of a translucent façade is the collapse or fall-out of fragments of the translucent façade filling that contribute to the spread of fire in the building. By analyzing the experience of tests carried out fragments of buildings with FTS with simulated thermal and/or fire (flame torch) effects, the following factors are taken into account: wind loads with variable directions of air flows; access of fire-fighting and rescue units, etc. During full-scale FTS tests, a possible scenario of fire development is simulated, taking into account the fragment and features of the specimen, the fire load that affects the development of fire along the façade, the structural design of the FTS, - glass (conventional and fireresistant) and structural elements. The authors suggest that in order to ensure fire safety of high-rise buildings with FTS the fire-resistance limit assessment should be carried out on fragments of buildings with a simulation of thermal and/or fire impact, which is close to the real conditions.
\end{abstract}

\section{Introduction}

The façade translucent structures (FTS) simultaneously act as an external non-load bearing wall $[1,2]$.

Fires are particularly dangerous for high-rise and top buildings due to the peculiarities of their design and planning, purpose, technology of their construction and subsequent operation.

* Corresponding author: tanklevskiy@gmail.com 
More than four hundred fires in high-rise buildings have been recorded in Russia since 1997. Fires in such buildings are particularly dangerous, as the fire quickly spreads along the façade to other floors, with increasingly devastating consequences. Such fires are harder to extinguish and people are more difficult to evacuate from the upper floors.

The largest high-rise building fire in Russia took place in the city of Grozny in the Chechen Republic. In April 2013, the Olimp Tower in the Grozny City skyscraper complex caught fire (Figure 1, a). The flames engulfed the entire building, from the 2 nd to the 40th floors. The fire was not extinguished until 7 hours after it started. This case also shows that Russia does not have enough special machinery and equipment to extinguish fires at such a height. Abroad, a similar fire occurred in a 33-storey skyscraper in South Korea in October 2020 (Figure 1, b).

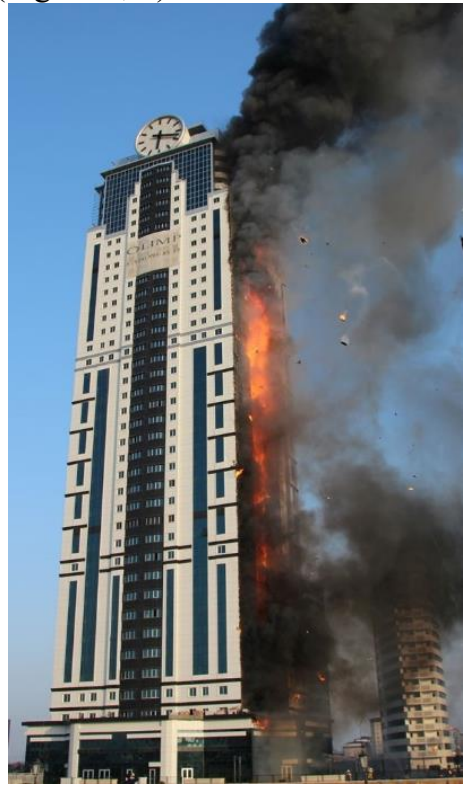

a)

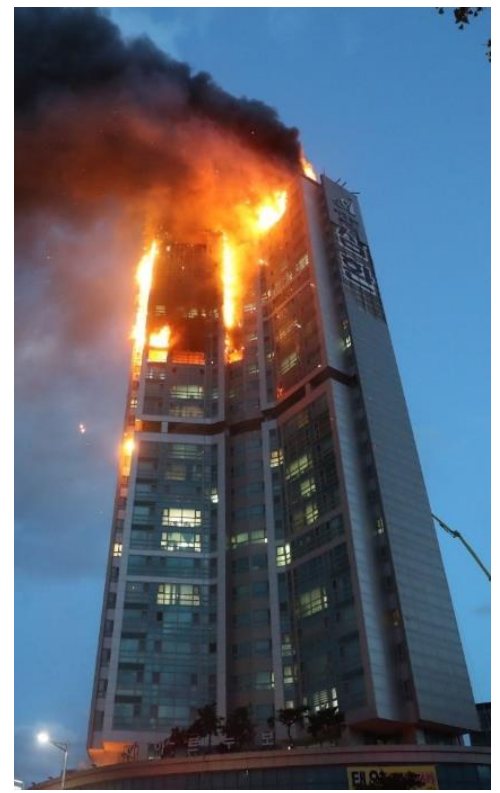

b)

Fig. 1. Examples of fires in high-rise buildings: a) Grozny City; b) Ulsan in South Korea

Fires in high-rise buildings are characterised by devastating consequences [3, 4], such as the Grenfell Tower fire in London on 14.06.2017, Marina Torch skyscraper fire in Dubai on 04.08.2017, the 54-storey skyscraper fire (in the basement of a nearly completed building, part of famous Toranomon Hills complex) in Tokyo on 18.11.2020.

These cases show that flame spreads particularly rapidly along the façade to other floors in high-rise buildings during a fire

There is no universal, single method for extinguishing fires at high altitude. In 2017, Moscow was the first place in the world to test four methods of supplying extinguishing agents to the 373-meter mark of the Federation Tower. Those methods were the following: water delivery using fire motor pumps was practiced, gas-filled foam delivery using a CAFS unit, and water delivery using a Cobra water-jet, as well as water delivery from a highpressure fire pump installed on a fire truck [5]. All these methods require a considerable amount of time as well as a large amount of manpower and resources for laying hose lines. The tactical and technical characteristics of robotic firefighting complexes are poorly studied. One of the areas of fire safety of high-rise buildings is studying of stability of façade translucent structures based on the simulation of a probable scenario of fire development in high-rise buildings with FTS. 
In a real fire, by resilience (fire resistance) of a translucent façade the ability of the façade to withstand destruction is understood.

The criterion for the loss of fire resistance of a translucent façade is a collapse or fall out of fragments of a translucent façade filling that contribute to spread of fire through the building.

During full-scale FTS tests we simulate a probable scenario of fire development, taking into account fragment and specimen characteristics, fire loads that influence fire development on the facade, FTS structural design - glass (conventional and fire-resistant) and structural elements, because spread of fire hazards due to thermal deformations of structures occurs through horizontal and/or vertical connection elements into the adjacent premises.

The aim of the analysis is to identify approaches to the development of a test method for determining the actual fire resistance limit of façade translucent structures based on the modeling of a probable fire scenario in high-rise buildings with FTS.

The primary objectives of the research are:

- to analyze the main provisions of the regulatory and technical documentation in terms of fire safety requirements for the FTS of high-rise buildings;

- to substantiate basic provisions for the method of full-scale fire test to assess fire resistance of FTS of a high-rise building;

- to give suggestions on modeling of probable scenario of fire development in high-rise buildings with FTS, which should be performed taking into account fragment and features of the sample, fire load, which affects the development of fire along the façade.

In general, studies of actual fire resistance of façade translucent structures for high-rise buildings have been carried out using standard methods, which contradicts the conditions for assessing the actual fire resistance, directly related to the spread of fire across the façade in real conditions. Therefore, the main objectives in developing a test method for determining the actual fire resistance rating of FTS are:

- analysis of fire development to determine the resistance of different types of structural schemes of buildings of different number of floors made of FTS [6-10],

- application of active and passive fire protection to possibly reduce fire resistance limits of FTS,

- developing of basic provisions of a method on the basis of a test programme for a full-scale fragment of FTS, taking into account their location in front of a slab, as well as a method of fastening - to the slab ends, bearing capacity of fastening nodes.

In the Russian Federation, requirements for fire resistance limits of FTS are determined by requirements for fire resistance limits of external non-load-bearing walls, which include a required minimum fire resistance limit for various types of walls (including those with fireresistant glass infill) equal to E30 for buildings, structures and fire compartments of fire resistance degree I and E15 for fire resistance degrees II, III, IV.

Analyzing the experience of tests carried out in Europe on fragments of buildings with FTS up to 10 floors high with simulated thermal and/or fire (flame torch) effects, the following factors are taken into account:

- wind loads with variable airflow directions;

- access of fire-fighting units to extinguish the fire and rescue people (taking into account the actual equipment) $[4,11]$.

In the Russian Federation there are results of tests carried out on fragments of buildings with FTC up to 2 floors high with simulated fire loads inside the building.

In Russia, standard methods of fire tests partially take into account the characteristic features of structural solutions of FTS and possible scenarios of fire development related to them. Therefore, for a reliable assessment of the actual fire resistance limit, full-scale testing with simulation of the probable scenario of fire development, including the triggering of automatic fire extinguishing systems, is needed. 
For example, in the Russian Federation there is experience in the development of test methods to determine the fire resistance limit of FTS for high-rise buildings using sprinkler extinguishing $[12,13]$.

\section{Materials and methods}

The research was carried out for a compartment with I degree of resistance with increased fire-resistance limits of individual building structures; structural fire risk class - C0.

New sprinklers are suggested to be used in such tests (fig. 2).

Sprinkler DUOZZ-ZHNGo/KU2 V32 according to GOST R 51043-2002 (code name "Tuman") is designed for extinguishing and localization of fire and creating of water curtains.

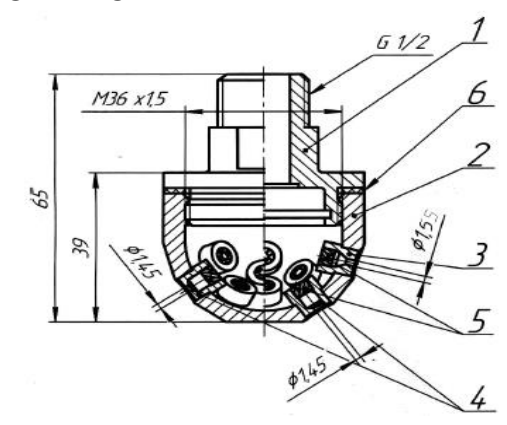

Fig. 2. Structure of an experimental nozzle: 1 - frame; 2 - sprayer; 3 - plug; 4 - blank cap; 5 - filter; 6 - discharge nozzle.

WM LP nozzle with screw thread ( 8 holes of $1.45 \mathrm{~mm}$ diameter; 4 holes of $1.7 \mathrm{~mm}$ diameter in the top row) with square spray form was designed and used for the first time.

It is shown that with increasing the diameter of the centrifugal nozzle, its characteristics (protected area, intensity, performance, etc.) improve [14,15].

Tests allow us to conclude that the sprinkler of this design can be used only for extinguishing class $\mathrm{A}$ fires and requires further development to increase the area of application.

During the tests, the sprinklers were installed at a height of $2.5 \mathrm{~m}$ from the top cut of the collection pans. One of the four $1,55 \mathrm{~mm}$ diameter holes in the sprayer was oriented diagonally to the square on which the pans were installed (Figure 3).

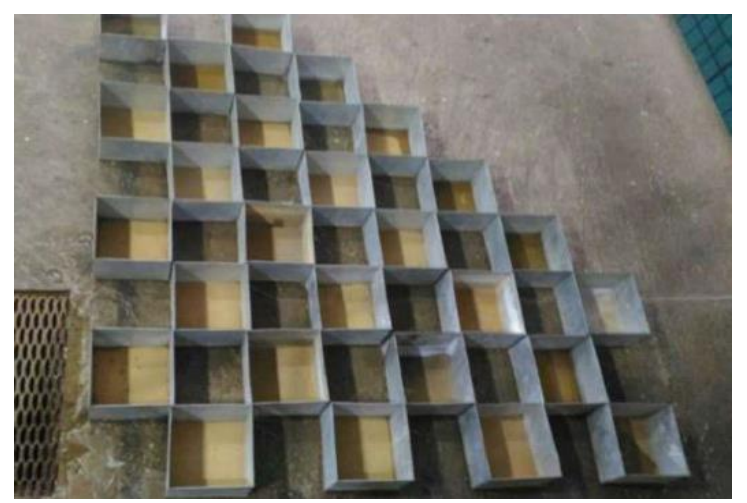

Fig. 3. Location of collection pans during tests. 
Such location is reasoned by the fact that the nozzle forms a square shaped spray area and has two rows of holes. The lower row consists of 8 holes of $1,45 \mathrm{~mm}$ diameter and the upper row consists of 4 holes of $1,55 \mathrm{~mm}$ diameter, directed diagonally to the square. During the test, water was supplied from the pipeline at pressures of 0,$5 ; 0,7 ; 0,9 ; 1,1 \mathrm{MPa}$. The duration of water supply was $180 \mathrm{sec}$.

Average spraying intensity $\mathrm{I}, \mathrm{dm}^{3} /\left(\mathrm{m}^{3 *} \mathrm{~s}\right)$ was calculated via formula:

$$
I=\frac{\sum_{i=1}^{n} i_{i}}{n}
$$

$i_{i}$ - spaying intensity of $i$ collection pan, $\mathrm{dm}^{3} /\left(\mathrm{m}^{3 *} \mathrm{~s}\right), n-$ quantity of collection pans on the protected area.

Spraying intensity of $i$ collection pan, $\mathrm{dm}^{3} /\left(\mathrm{m}^{3 *} \mathrm{~s}\right)$ was calculated via formula:

$$
i_{i}=\frac{v_{i}}{0.0625 t}
$$

$V_{i}$ - water volume, collected in $i$ collection pan, $\mathrm{dm}^{3}, t$ - spraying time, $\mathrm{s}$.

Spraying uniformity $S, \mathrm{dm}^{3} /\left(\mathrm{m}^{2 *} \mathrm{~s}\right)$, was calculated via formula:

$$
S=\sqrt{\frac{\sum_{i=1}^{n} i_{i}^{2}-\frac{\left(\sum_{i=1}^{n} i_{i}\right)^{2}}{n}}{n-1}} .
$$

Spraying uniformity index $R$ was calculated via formula:

$$
R=\frac{S}{i_{c p}}
$$

The nozzle was considered to have passed the test at an average spraying intensity above the norm with a spraying uniformity index of less than 0,5 . The number of collection pans with a spraying intensity not exceeding $50 \%$ of the norm was not more than two.

\section{Results and discussion}

During the tests, placement of "Tuman" sprinkler was low. After finishing of water supply from the sprinkler, the data on the amount of water in each of the collection pans was recorded. A sprinkler test report was drawn up based on the results of the experiments. The data was analyzed and spraying patterns were drawn.

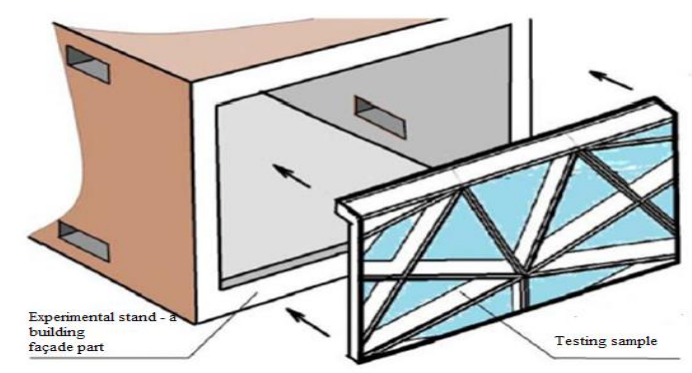

Fig. 4. Diagram of external façade installation 
Façade designed as a hinged glassed-in façade system, partly has a double-stranded design in which the space between the two strands of glass are used to create double-light buffer zones that perform an energy-saving function.

For the first time in the Russian practice a new test method has been developed to determine actual fire resistance of FTS for high-rise buildings; tests were carried out in accordance with the "Program of full-scale tests of a fragment of translucent vertical building with sprinkler system".

The following basic requirements to structures and materials were considered

Suspended façade:

- Double façade system:

- internal glass perimeter E 30;

- external glass perimeter is not regulated (K0);

- Single façade system:

- external glass parameter: E30.

One option for implementing these requirements is the use of structures with nonstandardized fire resistance in combination with water spraying.

The authors propose a test method for determining the fire resistance limit of FTSs for high-rise buildings, taking into account the following:

- the mullion-transom system and translucent fillings considerably exceeding the area of windows, which are exposed to fire from the outside;

- attachment points to ceilings and/or walls;

- connections with protection elements (sealing of the horizontal and/or vertical connections of the fastening system to the ceiling or load-bearing walls);

2) the actual assessment of the fire resistance of FTS is carried out in a simulated fire, as for a full-scale fragment of the façade, taking into account attachment points and connections (including anchors) adjacent to the structures;

3) for full-scale tests of the FTS in a simulated real fire, the specimen should include the translucent filling and the inter-floor belt with attachment points and connections (including anchor connections), over- and under-sill panels (if any in the design project);

4) limiting conditions of the translucent part of the structures shall be determined by the loss of integrity $\mathrm{E}$ and the thermal insulating capacity $\mathrm{W}$;

5) limiting conditions of the inter-floor chord, above- and under-sill panels shall be determined by integrity $\mathrm{E}$ and insulating capacity $\mathrm{I}$.

\section{Conclusion}

It is possible to estimate actual fire resistance limits of FTS based on the results of scientific research and the requirements of regulatory documents on fire safety.

The authors offer a method of full-scale fire test to assess fire resistance of FTS of a highrise building, which creates pre-requisites for updating of normative and technical documentation in terms of fire safety requirements for FTS of high-rise buildings.

Options of increasing fire resistance of FTS of buildings can be developed only on the basis of results of scientific research on modeling of probable scenario of fire development in high-rise buildings with FTS, which should be made taking into account the fragment and features of the sample, fire load, which affects the development of fire on the facade. It is also necessary to consider the structural design of the FTS, - glass (conventional and fireresistant) and structural elements, because the spread of fire hazards due to thermal deformations of structures occurs through horizontal and/or vertical connection elements to nearby premises. 
This work was supported by the Ministry of Science and Higher Education of the Russian Federation (project \#FSWG-2020-0007).

\section{References}

1. SP 267.1325800.2016. High-rise buildings and complexes. Design rules. [Electronic resource]: a set of rules // KODEKS Consortium: an electronic fund of legal and regulatory technical literature. - Electron. Dan. - M., 2017. - Access mode: http://docs.cntd.ru/document/456044284 (date of access 20.02.2019)

2. EN 1991-1-2: 2002 [88] Eurocode 1: Actions on structures -- Part 1-2: General actions - Actions on structures exposed to fire [Electronic resource]: PhD Engenharia. - Access mode: https://www.phd.eng.br/wp- content / uploads / 2015/12 / en.1991.1.2.2002.pdf (date of access 18.02.2019)

3. T.Yu. Eremina, Egorov I.A., Problems of evacuating people from high-rise buildings in case of fires, Internet-journal "Technosphere Safety Technologies", No. 3 (55), 2014.

4. K.S. Vlasov, Danilov M.M., Denisov A.N., Large fires - selection criteria, Fire safety, No. 3 (100), 2020.

5. T. Borisov, Reach a skyscraper, Rossiyskaya gazeta - Federal number № 192(8246) (https://rg.ru/2020/08/27/reg-cfo/v-moskve-ispytali-sistemu-tusheniia-pozharov-vneboskrebah.html)

6. Interfloor belt $1000 \mathrm{~mm}$ high of an external non-bearing hinged translucent enclosing structure made of aluminum profiles of the TP-5030 system (CJSC Tatprof), with nonfire-resistant translucent filling [Electronic resource]: test report No. 39 sk / i-2014 // Aluminum building structures, Access mode: http: //www.ask-profi.ru/license/2/ (access date 04/17/2019)

7. Fragment (interfloor belt) of an external non-load bearing curtain translucent structure made of aluminum profiles of the ALT F50 system (AluminTechno), $1100 \mathrm{~mm}$ high, the lower overhang $322 \mathrm{~mm}$, the upper part $575 \mathrm{~mm}$ and the spacing of the posts 1475 mm [Electronic resource]: test report № 14 sk / i-2014 // Company "Horizonov": website. - Access mode: http://www.horizonov.ru/window-system/alutech/alt-f50/ (date of treatment 03/28/2019).

8. Technical conclusion on the assessment of the fire-technical characteristics of fragments (interfloor belts) of non-bearing hinged translucent fencing structures with a frame made of aluminum profiles of the ALT F50 Alumin Techno system [Electronic resource]: ALUTECH Group of Companies: website. - Access mode: https: // alutechgroup.com/content/news/2016/09/09/1.pdf (date of access 03/16/2019)

9. E.V. Zubkova, Factors of destruction of sheet glass in a fire [Electronic resource], Technologies of Technosphere Safety: Internet Journal. - 2015. - No. 4 (62). Access mode: http://academygps.ucoz.ru/ttb/2015-4/2015-4.html (date of access 04/01/2019)

10. Temporary methodology of fire tests of external non-bearing (including curtain) walls with translucent elements to determine their fire resistance and fire hazard [Electronic resource]: methodology SNIPOV.net: website. - Access mode: http://snipov.net/c_4651_snip_113906.html (date of access 03/21/2019)

11. Prevention and suppression of fires in high-rise buildings and high-rise buildings with ventilated facades // Tutorial.

12. E.V. Zubkova, Influence of water irrigation on fire resistance of fire-resistant translucent filling of building structures, dis. Candidate of technical sciences: 05.26.03 / Zubkova Elena Vladimirovna. - M., 2015 .- 182 p.

13. M.M. Kaziev, E.V. Zubkova, Algorithm for the protection of fire-resistant translucent structures in case of fire, Fires and Emergencies: Prevention, Elimination. - 2015. - No. 
3. - P. 71-78.

14. N. Kropotova, L. Tanklevskiy, V. Yakovlev, Coordination of special technical conditions for civil defense and protection in emergencies in Russia, IOP Conference Series Materials Science and Engineering 666:012100, 2019

15. N. Kropotova, A. Arakcheev, L. Tanklevskiy, A. Tanklevskiy, Low pressure watermist nozzle with a swirl worm screw inserts, MATEC Web of Conferences 245(21):11001, 2018 